\title{
Ultrafiltration for Purification and Treatment of Water Streams in Swimming Pool Circuits
}

\author{
Edyta Łaskawiec ${ }^{1 *}$, Mariusz Dudziak', Joanna Wyczarska-Kokot ${ }^{1}$ \\ 1 Institute of Water and Wastewater Engineering, Silesian University of Technology, Konarskiego 18, \\ 44-100 Gliwice, Poland \\ * Corresponding author's e-mail: edyta.laskawiec@polsl.pl
}

\begin{abstract}
The paper presents possible applications of pressure-driven membrane processes for treatment of swimming pool water and purification of waste streams - washings. Newly identified swimming pool water quality issues are presented that require a modernization of existing technologies. The studies used polymer membranes with the same particle distribution range (50000 Da), but made of different membrane-forming materials: polyvinylidene difluoride (PVDF) and polyether sulfone (PES) for purification of washings. The ultrafiltration process allowed obtaining a high turbidity reduction rate in washings (over $95 \%$ ), and also a significant reduction of total organic carbon. The effectiveness of the PES membrane was reduced after the process commencement, whereas the separation capacity of the PVDF membrane increased during the studied filtration process. While setting the operational process parameters consideration should be given also to the resistance of used membranes to chlorine present in the swimming pool water. A prolonged exposure of the polyether sulfone membrane to chloride may have caused its gradual damage and degradation of its separation properties.
\end{abstract}

Keywords: swimming pool water, pressure-driven membrane processes, closed circuit water systems, water treatment systems, water recovery

\section{INTRODUCTION}

In order to maintain the required physical and chemical as well as microbiological standards of water, each public swimming pool must have its own treatment circuits [Regulation of the Minister of Health, 2015; Chief Sanitary Inspectorate 2014]. These are closed circuits in which water is treated and disinfected continuously as the facility is in operation. The water disinfection has a key significance in preventing the growth of pathogenic microorganisms. Swimming pools are filled mainly with municipal water, more rarely with water from in-house drilled wells. The feed water contains its naturally occurring organic and inorganic compounds, and disinfection by-products [Zang et al., 2017]. Additional impurities can penetrate into the municipal water also during its transfer to the swimming pool [Li et al., 2017]. However, the main factors which cause degradation of water quality in basins are organic micro- pollutants introduced by the swimming pool users (e.g. residues of cosmetic products) and human metabolism products (saliva, urine, sweat, epidermis) [Carter and Joll, 2017; Yeh et al., 2014]. The number of identified compounds which belong to the group of disinfection by-products has already exceeded 600. A high interest in these compounds is related to their potential adverse effect on the human organism [Farré et al., 2013; Glauner et al., 2005].

\section{Identified health hazards for swimming pool users}

The swimming pool water environment is a unique system in which the water quality is affected by many factors, inter alia feedwater quality, number of swimming poll users, treatment technology (including the type of filtration bed) and the swimming pool type (indoor or outdoor). In order o maintain the required physical and 
chemical and microbiological standards of water its treatment must be accompanied by disinfection. Chemical disinfectants reduce the growth of pathogenic microorganisms, e.g. Escherichia coli, Legionella sp. in the swimming pool water [Briancesco et al., 2014], simultaneously reacting with various pollutants present in the water.

Presence of disinfection by-products (DBP) in swimming pools is a more frequently and more widely studied problem [Kanan and Karanfil, 2011; Spiliotopoulou et al., 2015]. Thanks to the progress in instrumental analysis, many disinfection by-products in the swimming pool water have been identified in recent decades [Cyril et al., 2012]. The ubiquity of trihalomethanes (THM), haloacetic acids (HAA), halogen acetonitriles (HAN), chloramines (CAM) and many other chemical compounds proves that a prolonged and/ or regular contact with the swimming pool water and air can have serious effects for the health of the swimming pool users [Boucherit et al., 2015; Zwiener et al., 2007; Glauner et al., 2005].

In addition to natural organic matter (NOM), the municipal water used in swimming pools contains also chlorides, bromates and disinfection by-products, including chloramines, bromamines [Cartell and Joll, 2017; Zang et al., 2017]. Natural products of human metabolism play an important part in formation of disinfection by-products. A single swimmer during one hour of physical exertion secretes $50 \mathrm{ml}$ of urine and $200 \mathrm{ml}$ of sweat which contributes to feeding water with amino acids, creatinine, uric acid, urea, citric acid, or sodium chloride. A higher reactivity of body fluids analogs (BFA) with chlorine when compared to NOM has been verified. The BFA mixture forms more haloacetic acids (HAA) than trihalomethanes (THM); in addition a large importance in formation of of THM and HAA has been attributed to citric acid [Cartell and Joll, 2017; Kanan and Karanfil, 2011].

The secreted urine contains also active ingredients and metabolized products of analgesics and antibiotics which, in combination with residues of cosmetics transferred to the water on skin and hair, form a numerous and differentiated group of disinfection by-products [Chowdhury et al., 2014]. The group is growing to include newly identified compounds, among which important are decomposition or reaction products from UV filters UV and parabens - benzophenone, p-aminobenzoic acid, or ethylhexyl methoxycinnamate [Santos et al., 2012; Teo et al., 2015].
Although the concentration of many disinfection by-products in the tested swimming pool water is below $1 \mathrm{mg} / \mathrm{L}$ [Yeh et al., 2014], their very presence if harmful for bathers. It has been verified that that micropollutants (disinfection byproducts) form various enzymes which cause an oxidation stress in cells of living organisms [Farré et al., 2013]. Many studies on th swimming water quality have confirmed the genotoxic, cytotoxic and mutagenic properties of DBP [Glauner et al., 2005; Farré et al., 2013; Yeh et al., 2014].

\section{Effectiveness of unconventional swimming pool treatment methods}

The bed filtration process in the swimming pool treatment circuits is accompanied by contact coagulation. However, the effectiveness of coagulation process in removing micropollutants (particularly small-molecular) is low, about $10-20 \%$ [Nowacka et al., 2014; Acero et al., 2016]. In addition, many water treatment systems in swimming pools still use single-layer sand filtration beds which do not guarantee the total removal of pathogenic microorganisms [Bodzek, 2013]. The filtration bed effectiveness can be increased by using an additional sorptive layer of active carbon. Depending on the type of micropollutants, the effectiveness the removal degree can reach from 20 to 85\% [Altmann et al., 2016].

Pressure-driven membrane processes can be an alternative to the classic water treatment systems. Such processes combine high effectiveness in removal of suspended solids, microorganisms, disinfection by-products and micropollutants [Bodzek, 2013]. Ultrafiltration (UF) is highly effective in removing natural organic matter and micropollutants from water solutions [Acero et al., 2010; Bodzek, 2013; Rodriguez-Narvaez et. al., 2017]. The UFOX 10 systems with membrane pore size of $0.01 \mu \mathrm{m}$ are an example of effective UF systems which allow purification of washings and improvement of the swimming water quality [Wallace \& Tiernan GmbH, 2006]. Advancements in studies on waste stream treatment and reuse in closed circuits can contribute to implementation of technologies that will allow a significant reduction of water consumption with economic and ecological benefits.

In the light of latest reports on pollutants and their harmfulness to the health of swimming pool users, it is necessary to revise the effectiveness of currently used purification methods. 
The paper aimed at presenting unconventional solution that in the future may find application in the swimming pool circuits. The need for changes in the swimming pool circuits was justified by indicating newly diagnosed problems with swimming pool water quality. The authors have shown the selected results of studies and conclusions from research on application of pressure-driven membrane processes in removal of problematic pollutants from the swimming pool water.

\section{METHODS}

\section{Membrane filtration methods}

The washings used in the study consisted of the stream of wastewater from the rinsing of multilayer pressure filters (activated carbon-quartz sand) installed in a hot tubs water purification system. The object is characterized by a high load of bathers (at the time of collection 25 people use the swimming pool hall) . Flat ultrafiltration membranes made by Osmonics Inc. (USA), with different physicochemical parameters, were used in the tests.

The membranes were placed in a steel filtration cell with the volume of $380 \mathrm{~cm}^{3}$ where the active surface of the membrane was equal to $0,00385 \mathrm{~m}^{2}$. Before the filtration started, the new membranes were conditioned by filtering deionized water in order to stabilize the volume of the permeate stream. The process was performed in a one-direction filtration layout. The permeate in $0,00005 \mathrm{~m}^{3}$ volume was collected six times, with the feed being replenished in the system.

The transport characteristics of membranes used in the filtration processes were assessed on the basis of volumetric stream of deionized water $\mathrm{J}_{\mathrm{w}}$ (measured upon the membrane being conditioned with water) and $\mathrm{J}_{\mathrm{w}}$ (measured upon proper filtration) using the following equation:

$$
J_{w}=\frac{v}{F \cdot t} ; \frac{m^{3}}{m^{2} s}
$$

where: $v$ is the volume of water of permeate in $\mathrm{m}^{3}$;

$F$ is the active surface area in $\mathrm{m}^{2}$, and $t$ is the time of filtration in s.

Retention (R) was determined as part of the assessment of the separation characteristics of membranes, its value being calculated from the reductions in individual contamination rates:

$$
J_{w}=\frac{v}{F \cdot t} ; \frac{m^{3}}{m^{2} s}
$$

where: $c_{p}$ is the concentration of contaminants within the permeate (index value) and $c_{n}$ is the concentration of contaminants in the feed (index value).

The intensity of the reduction of the transport properties of the membrane (the degree of pore blocking) was determined from the relative volumetric stream of the permeate:

$$
\alpha=\frac{J_{w}}{J_{v}}
$$

where: $J_{w}$ is the volumetric stream of the permeate at the sixth point of measurement in $\mathrm{m}^{3} / \mathrm{m}^{2} \cdot \mathrm{s}$, and

$J_{V}$ is the volumetric stream of deionized water in $\mathrm{m}^{3} / \mathrm{m}^{2} \cdot \mathrm{s}$.

\section{Analytical procedures}

The quality of the washings was assessed before and after the treatment on the basis of selected physicochemical parameters. The measurements of the conductivity and $\mathrm{pH}$ of samples were carried out using a multiparametric ino$\mathrm{Lab}^{\circledR} 740$ meter (WTW). Ultraviolet absorbance at $254 \mathrm{~nm}$ was measured using an UV VIS Cecil 1000 spectrometer from Analytik Jena AG using a sample cell with optical path $\mathrm{d}$ of $1 \mathrm{~cm}$. $\mathrm{UV}_{254}$ absorbance values were measured according to a method disclosed by US EPA [Potter and Wimsatt 2009] The turbidity of samples was assessed by means of a TN-100 turbidimeter from EUTECH

Table 1. Characteristics of membranes and operating parameters of the process

\begin{tabular}{|c|l|l|l|c|c|c|}
\hline Process & \multicolumn{1}{|c|}{$\begin{array}{c}\text { Membrane } \\
\text { symbol }\end{array}$} & Membrane material & $\begin{array}{c}\text { Limit molar } \\
\text { mass, Da }\end{array}$ & $\begin{array}{c}\text { Process } \\
\text { pressure, MPa }\end{array}$ & $\begin{array}{c}\text { Volume flow rate of } \\
\text { deionized water J. } \\
\mathrm{m}^{3} / \mathrm{m}^{2} \cdot \mathrm{s}\end{array}$ & $\begin{array}{c}\text { Recovered } \\
\text { permeate } \\
\%\end{array}$ \\
\hline \multirow{2}{*}{ UF } & YMBN3001 & $\begin{array}{l}\text { Polyvinylidene } \\
\text { difluoride (PVDF) }\end{array}$ & 50000 & 0.2 & 11.86 \\
\cline { 2 - 6 } & YMPTSP3001 & $\begin{array}{l}\text { Polyethersulfone } \\
\text { (PES) }\end{array}$ & 50000 & 0.2 & 26.10 \\
\hline
\end{tabular}

${ }^{*}$ Tested independently for each filtration cycle. 
Instruments. Total organic carbon (TOC) was determined using an analyser series TOC-L using the catalytic oxidation method by combustion at $680{ }^{\circ} \mathrm{C}$ (Shimadzu). The chlorine concentration was measured with a spectrophotometer Specroquant ${ }^{\circledR}$ Pharo 100 (Merck). The selected physicochemical parameters are presented in the Table 2.

\section{RESULTS AND DISCUSSION}

The polyether sulfone membrane had more than twice higher value of volumetric deionized water stream, compared to a PVDF membrane (Table 1). During the washings ultrafiltration process this value was gradually reduced as a result of PES membrane pores being blocked by suspended solids present in washings. The membrane fouling phenomenon can be minimized by using the coagulation process before the membrane filtration [Kim et al., 2005; Fan et al., 2008; Alansari et al. 2016].

After more than eight hours into the process the $\mathrm{J}_{\mathrm{v}}$ value for the PES membrane was $25.83 \cdot 10^{-7}$ $\mathrm{m}^{3} / \mathrm{m}^{2} \mathrm{~s}$. On the other hand, the initial value of volumetric permeate stream for the PVDF membrane increased during the filtration, after measur15 hours of filtration, JV was $14.90 \cdot 10^{-7} \mathrm{~m}^{3} / \mathrm{m}^{2} \mathrm{~s}$. Thus, the relative of volumetric permeate stream for the PVDF was within the $1.09 \div 1.26$ range (Fig. 1). The $\alpha$ value for the polyether sulfone membrane was $0.99 \div 1.01$.

Both tested membranes were highly effective in removing sludge and suspended solids from washings. Raw washings had turbidity at the 19.20 NTU level. The retention rate for the ultrafiltration process with the PES membrane was between 92 and $97 \%$. But only in a half of the samples the value was below 1 NTU. The PVDF membrane had a slightly better separation capability, the retention coefficient was from 96 to $99 \%$, and all tested washing samples had turbidity below 1 NTU (Fig. 2).

In addition, analysed was the change of total organic carbon during the UF processes. The content in raw washings was $3.454 \mathrm{mgC} / \mathrm{L}$. The separation capability of the PVDF membrane for organic compounds significantly increased dur-

Table 2. Physicochemical parameters of the washings

\begin{tabular}{|l|c|c|}
\hline \multicolumn{1}{|c|}{ Parameter/Indicator } & Unit & Value \\
\hline $\mathrm{pH}$ & - & 6.84 \\
\hline Conductivity & $\mu \mathrm{N} / \mathrm{cm}$ & 1143.20 \\
\hline Turbidity & $\mathrm{NTU}$ & 19.20 \\
\hline Absorbance $\left(\mathrm{UV}_{254}\right)$ & $\mathrm{m}^{-1}$ & 12.00 \\
\hline Free chlorine & $\mathrm{mgCl}_{2} / \mathrm{L}$ & 0.40 \\
\hline Total chlorine & $\mathrm{mgCl}_{2} / \mathrm{L}$ & 0.74 \\
\hline Total organic carbon $(\mathrm{TOC})$ & $\mathrm{mgCl}^{2}$ & 3.454 \\
\hline
\end{tabular}

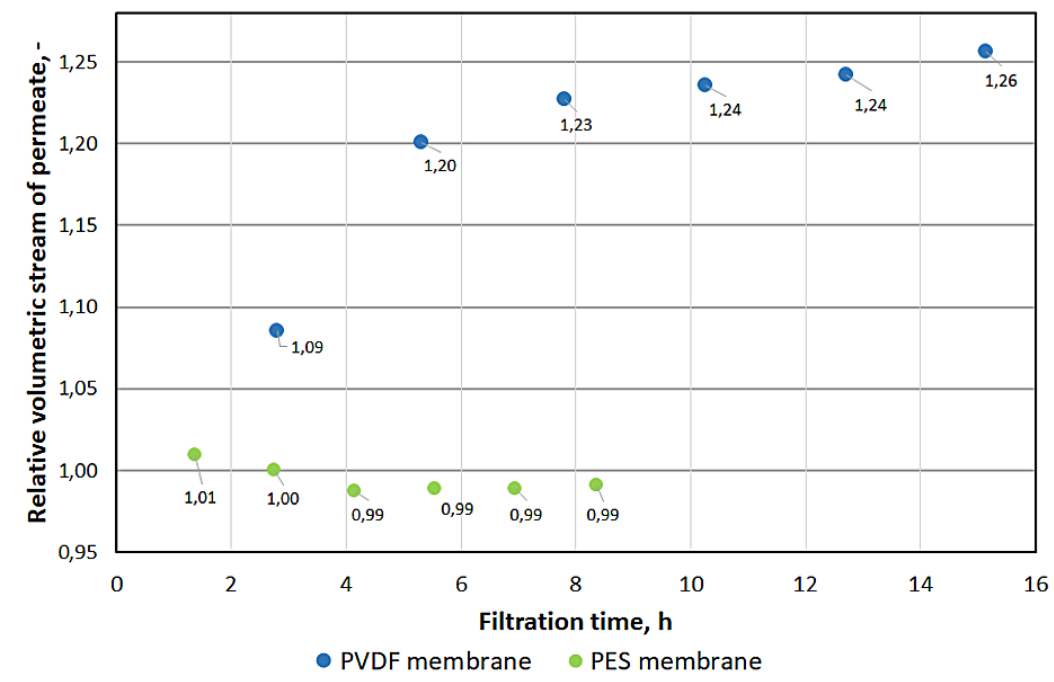

Figure 1. Relative volume permeate flux of the ultrafiltration membranes tested 


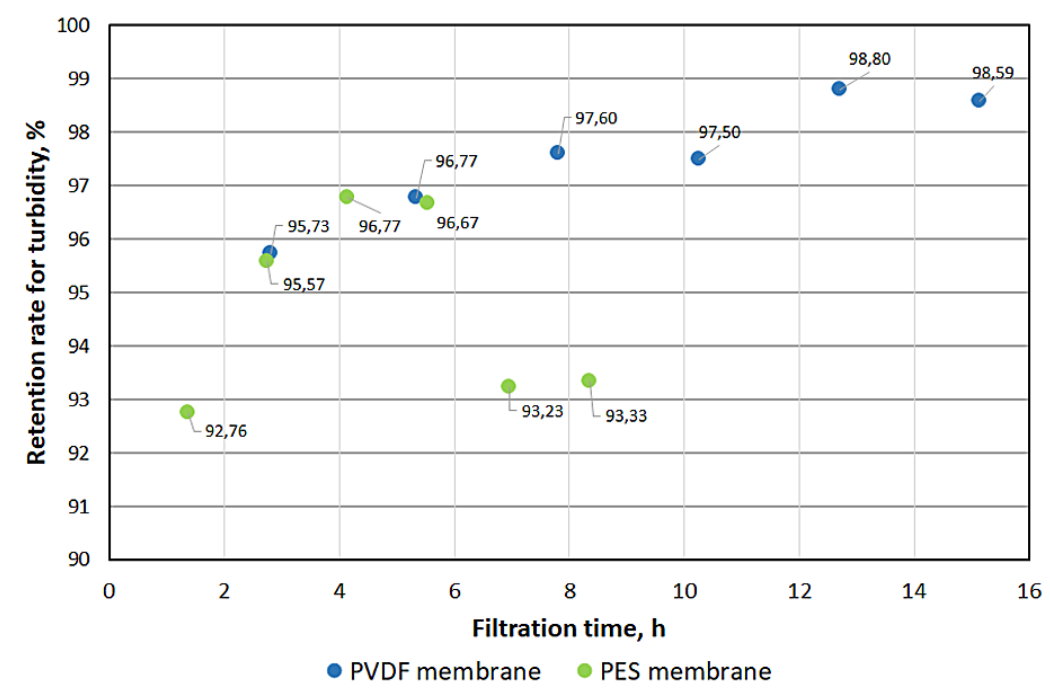

Figure 2. The value of the turbidity retention coefficient in the ultrafiltration processes of washings

ing the process (Fig. 3). The retention rate for the first sample was $12.30 \%$, and as much as $86 \%$ for the last sample (the TOC concentration was 0.462 $\mathrm{mgC} / \mathrm{L}$ ). The trend for the PES membrane was the opposite. Initial high TOC separation capability (R equal to 65\%) was reduced during the process. The final separation rate was about $22 \%$. When selecting the membrane material, it is necessary to take into account the many hours of contact of material with chlorine present in washings (total chlorine concentration $0.12-0.08 \mathrm{mg} / \mathrm{L}$ ).

Lowering the value of the retention coefficient of TOC parameter in UF with PES membrane, is related to the phenomenon of concentration of washings in the dead-end system. This phenomenon was not observed in the case of a membrane made of PVDF. A thorough analysis of the impact of pollution from pool water on the membrane surface is necessary. This would allow not only to ensure a high degree of pollution removal and to obtain high hydraulic efficiency, but also to use a membrane-based material with a sufficiently long service life.

\section{CONCLUSIONS}

1. Pressure-driven membrane processes are an alternative for the waste stream treatment methods due to a reduced need for dosing of chemicals. A partial return of washings treated during the ultrafiltration would allow a significant reduction of wastewater discharged from the swimming pool.

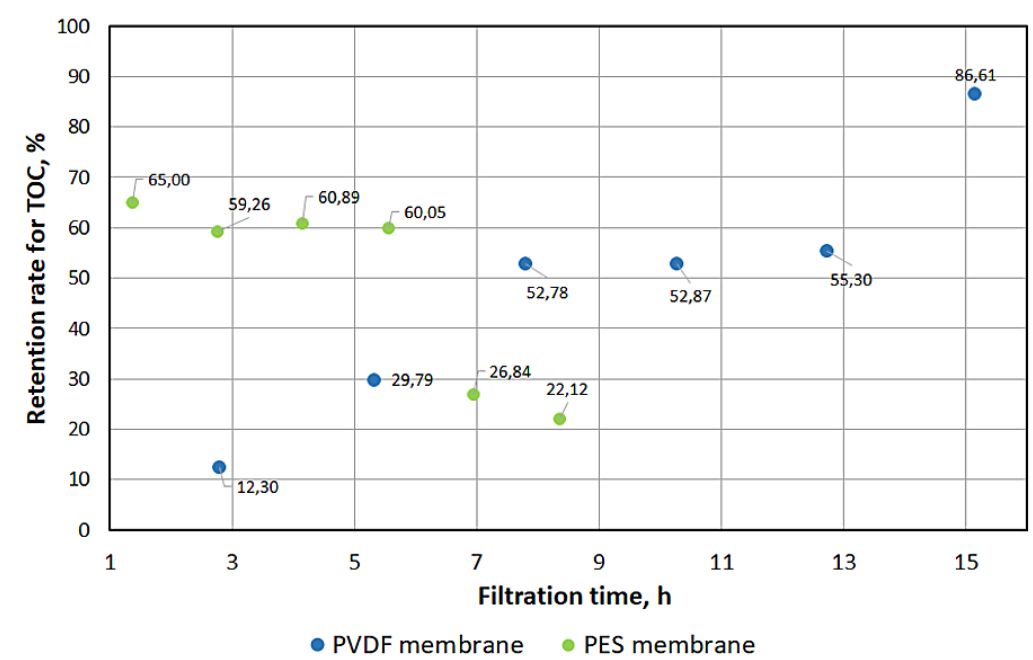

Figure 3. Change in the value of parameter of TOC retention coefficient in ultrafiltration washing processes 
2. The tested ultrafiltration membranes were highly effective in reduction of washing turbidity, over $90 \%$.

3 . The choice of membrane material is an important issue due to its contact with chlorine contained in pool water.

4. The effectiveness of TOC reduction depended on the type of membrane. In the case of the PVDF membrane, the effectiveness increased during filtration (from 12.30 to $86.61 \%$ ). However, it decreased for the PES membrane, from 65.00 to $22.12 \%$.

5. Presence of a large number of suspended solids particles in washings does not always reduce the hydraulic effectiveness of membranes. It can significantly improve the separation capabilities of membranes with larger pores (over $100 \mathrm{kDa}$ ). This entails the necessity of further studies of ingredients present in the swimming pool water, evaluation of their size and diversity. This would allow choosing the most favourable operational parameters of the filtration process.

\section{Acknowledgement}

Study conducted within the departmental research grant for young scientists (BKM- 554/ RIE-4/17) "Extended Physicochemical Evaluation of Swimming Pool Water".

\section{REFERENCES}

1. Acero J.L., Benitez F.J., Leal A.I., Real F.J., Teva F. 2010. Membrane filtration technologies applied to municipal secondary effluents for potential reuse, Journal of Hazardous Materials, 177, 390-398.

2. Acero J.L., Benitez F.J., Real F.J., Teva F. 2016. Micropollutants removal from retentates generated in ultrafiltration and nanofiltration treatments of municipal secondary effluents by means of coagulation, oxidation, and adsorption processes, Chemical Engineering Journal, 289, 48-58.

3. Alansari A., Selbes M., Karanfil T., Amburgey J. 2016. Removal of disinfection by-product precursors using hybrid coagulation-ceramic membrane systems, Journal American Water Works Association, 108 (10), E513-E522.

4. Altmann J., Massa L., Sperlich A., Gnirss R., Jekel M. 2016. UV254 absorbance as real-time monitoring and control parameter for micropollutant removal in advanced wastewater treatment with powdered activated carbon, Water Research, 94, 240-245.
5. Barbot E., Moulin P. 2008. Swimming pool water treatment by ultrafiltration-adsorption process, Journal of Membrane Science, 314, 50-57.

6. Briancesco R., Meloni P., Semproni M., Bonadonn L. 2014. Non-tuberculous mycobacteria, amoebae and bacterial indicators in swimming pool and spa, Microchemical Journal, 113, 48-52.

7. Bodzek M. 2013. Przegląd możliwości wykorzystania technik membranowych w usuwaniu mikroorganizmów i zanieczyszczeń organicznych ze środowiska wodnego [An overview of the possibilities of using membrane techniques in the removal of microorganisms and organic pollutants from the aquatic environment], Inżynieria I Ochrona Środowiska, 16(1), 5-37.

8. Boucherit A., Moulay S., Ghernaout D., Al-Ghonamy A.I., Ghernaout B, Naceur M.W., Messaoudene N.A., Aichouni M., Mahjoubi A.A., Elboughdiri N.A. 2015. New Trends in Disinfection By-Products Formation upon Water Treatment, Journal of Research \& Developments in Chemistry, 2015, 1-27.

9. Bunani S., Yörükoğlu E., Sert G., Yüksel Ü., Yüksel M., Kabay N. 2013. Application of nanofiltration for reuse of municipal wastewater and quality analysis of product water, Desalination, 315, 33-36.

10. Carter R.A.A., Joll C.A. 2017. Occurrence and formation of disinfection by-products in the swimming pool environment: A critical review, Journal of Environmental Sciences, 58, 19-50.

11. Chief Sanitary Inspectorate. 2014. Wytyczne w sprawie wymagań jakości wody oraz warunków sanitarno-higienicznych na pływalniach [Guidelines on water quality and sanitary conditions at swimming pools] www.gis.gov.pl.

12. Chowdhury S., Alhooshani K., Karanfil T. 2014. Disinfection by-products in swimming pool: Occurrences, implications and future needs, Water Research, 53, 68-109.

13. Cyril C., Simard S., Charest-Tardif G., Rodriguez M., Tardif R. 2012. Occurrence and Spatial and Temporal Variations of Disinfection By-Products in the Water and Air of Two Indoor Swimming Pools, International Journal of Environmental Research and Public Health, 9(8), 2562-2586.

14. Fan L., Nguyen T., Roddick F. A, Harris J.L. 2008. Low-pressure membrane filtration of secondary effluent in water reuse: Pre-treatment for fouling reduction, Journal of Membrane Science, 320, 135-142.

15. Farré M.J., Day S., Neale P. A., Stalter D., Tang J. Y.M., Escher B.I. 2013. Bioanalytical and chemical assessment of the disinfection by-product formation potential: Role of organic matter, Water Research, 47, 5409-5421.

16. Glauner T., Waldmann P., Frimmel F.H., Zwiener C. 2005. Swimming pool water-fractionation and 
genotoxicological characterization of organic constituents, Water Research, 39(18), 4494-4502.

17. Hang Ch., Zhang B., Gong T., Xian Q. 2016. Occurrence and health risk assessment of halogenated disinfection by-products in indoor swimming pool water, Science of the Total Environment, 543, 425-431.

18. Kanan A., Karanfil T. 2010. Formation of disinfection by-products in indoor swimming pool water: The contribution from filling water natural organic matter and swimmer body fluids, Water Research, 45(12), 926-932.

19. Kim S-H., Moon S-Y., Yoon Ch-H., Yim S-K., Cho J-W. 2005. Role of coagulation in membrane filtration of wastewater for reuse, Desalination, 173, 301-307.

20. Li Ch., Wang D., Xu X., Xu M., Wang Z. 2017. Spatial variations in the occurrence of potentially genotoxic disinfection by-products in drinking water distribution systems in China, Environmental Pollution, 31, 1463-1468.

21. Nowacka A., Włodarczyk-Makuła M., Bartłomiej Macherzyńskia B. 2014. Comparison of effectiveness of coagulation with aluminum sulfate and prehydrolyzed aluminium coagulants, Desalination and Water Treatment, 52, 19-21, 3843-3851.

22. Panyakapo, M., Soontornchai, S., Paopuree, P. 2008. Cancer risk assessment from exposure to trihalomethanes in tap water and swimming pool water. Journal of Environmental Science, 20(3), 372-378.

23. Potter B. Wimsatt J. 2009. Determination of total organic carbon and specific UV absorbance at 254 $\mathrm{nm}$ in source water and drinking water. EPA Document, Method 415.3.

24. Regulation of the Minister of Health from November 2015 on the requirements that water in swimming pools should meet (Dz. U. 2015 poz. 2016).

25. Reissmann F.G., Schulze E., Albrecht V. 2005. Application of a combined UF/RO system for the reuse of filter backwash water from treated swim- ming pool water, Desalination, 178, 41-49.

26. Richardson S.D., De Marini D.M., Kogevinas M. 2010. What's in the pool? A comprehensive identification of disinfection by-products and assessment of mutagenicity of chlorinated and brominated swimming pool water. Environmental Health Perspectives, 118, 1523-1530.

27. Rodriguez-Narvaez O.M., Peralta-Hernandez J.M., Goonetilleke A., Bandala E.R. 2017. Treatment technologies for emerging contaminants in water: A review, Chemical Engineering Journal, 323, 361-380.

28. Santos J.M., Miranda M.S., Esteves da Silva J.C.G. 2012. The degradation products of UV filters in aqueous and chlorinated aqueous solutions, Water Research, 46, 3167-3176.

29. Spiliotopoulou A., Hansen K.M.S., Andersen H.R. 2015. Secondary formation of disinfection by-products by UV treatment of swimming pool water, Science of the Total Environment, 520(1), 96-105.

30. Teo T.L.L., Coleman H.M., Khan S.J. 2015. Chemical contaminants in swimming pools: Occurrence, implications and control, Environment International, 76, 16-31.

31. Wallace \& Tiernan GmbH. 2006. UF system reduces swimming pool costs, Membrane Technology, July, 5-6.

32. Yang L., She Q., Wan M.P., Wang R., Chang V.W.C., Tang Ch.Y. 2017. Removal of haloacetic acids from swimming pool water by reverse osmosis and nanofiltration, Water Research, 116, 116-125.

33. Zhang Y., Chu W., Yao D., Yin D. 2017. Control of aliphatic halogenated DBP precursors with multiple drinking water treatment processes: Formation potential and integrated toxicity, Journal of Environmental Sciences, 58, 322-330.

34. Zwiener C., Richradson S.D., De Martin D.M., Grumut T., Glauner T., Frimmel F.H. 2007. Drowning in Disinfection Byproducts? Assessing Swimming Pool Water. Critical Review, Environmental Science \& Technology, 41(2) 363-372. 